\title{
Analysis of the Impact of Decreasing District Heating Supply Temperature on Combined Heat and Power Plant Operation
}

\author{
Alona Bolonina ${ }^{1}$, Genadijs Bolonins ${ }^{2}$, Dagnija Blumberga ${ }^{3},{ }^{1-3}$ Riga Technical University
}

\begin{abstract}
District heating systems are widely used to supply heat to different groups of heat consumers. The district heating system offers great opportunities for combined heat and power production. In this paper decreasing district heating supply temperature is analysed in the context of combined heat and power plant operation. A mathematical model of a CHP plant is developed using both empirical and theoretical equations. The model is used for analysis of modified CHP plant operation modes with reduced district heating supply temperature. Conclusions on the benefits of new operation modes are introduced.
\end{abstract}

Keywords - Combined heat and power optimisation, decreasing supply temperature, district heating.

\section{INTRODUCTION}

District heating systems (DHS) are widely used to supply heat to different groups of heat consumers. DHS offers great opportunities for combined heat and power (CHP) production thus providing efficient use of energy resources. Many investigations are dedicated to research and plan development both of the elements of DHS and of the system as a whole.

A number of recent studies come to the conclusion that district heating plays an important role in the implementation of future sustainable energy systems. However, the same reports also emphasize that the present DHS must undergo a radical change in low-temperature district heating networks interacting with low energy buildings as well as becoming an integrated part of smart energy systems [1].

According to the DHS classification offered in [1] supply temperature in Riga city DHS corresponds to 2nd generation systems where the pressurised hot water with a temperature $100^{\circ} \mathrm{C}$ and higher is used as a heat carrier.

Northern European countries, for example, Denmark, have great experience with DHS with decreased supply temperature. In Copenhagen DHS, in order to adjust the supply temperature to the lowest possible, temperature optimisation has been introduced [2], [3].

Moving towards lower supply temperatures gives the opportunity to reduce heat loss as well as increase electricity generation using cogeneration technology. Decreasing DHS supply temperature has a lot of benefits for the efficient operation of cogeneration plants. According to [4] reducing DHS supply temperature by $1{ }^{\circ} \mathrm{C}$ allows to increase electricity production by $0.2 \%-0.3 \%$ in a back-pressure steam turbine cycle. It is stated in [5] that lower DHS supply temperature affects the electricity production more than lower DHS return temperature. In one of the studies performed in Sweden, the potential gain from a $5^{\circ} \mathrm{C}$ lower DHS supply temperature is 4.2 GWh/year for the $170 \mathrm{MW} \mathrm{CHP}$ plant in Örebro and $6.2 \mathrm{GWh} /$ year for the $155 \mathrm{MW} \mathrm{CHP}+300 \mathrm{MW}$ heat plant in Västerås. Decreasing DHS return temperature by $5{ }^{\circ} \mathrm{C}$ would only give $1.1 \mathrm{GWh} /$ year or $1.7 \mathrm{GWh} /$ year, respectively [5].

In Riga DHS (the left bank of the Daugava River) an experimental decrease of DHS supply temperature was performed and described in [4], [6], [7]. For the purpose of carrying out the analysis of reducing DHS supply temperature, the heat supply areas of the HS Daugavgriva and HS Vecmilgravis were selected as actual models. The current temperature schedule of $130{ }^{\circ} \mathrm{C}-70^{\circ} \mathrm{C}$ was compared to lowered temperature schedule of $115^{\circ} \mathrm{C}-70^{\circ} \mathrm{C}$. The results showed that such a change of the temperature schedule led to the increase of DHS water flow by approximately $27 \%-28 \%$ and decrease of the heat loss in the network by approximately $5 \%$ [4], [6], [7].

The purpose of this paper is to analyse DHS supply temperature from another point of view - in the context of CHP plant operation. In this paper a mathematical model of a combined cycle gas turbine (CCGT) plant is described. The mentioned model was used to simulate new operating regimes of the plant and finding relations between DHS supply temperature and other plant operational parameters.

TABLE I

NOMENCLATURE

\begin{tabular}{|l|l|}
\hline$Q_{\mathrm{DH}}$ & DH heat capacity, MW \\
\hline$t_{\mathrm{r}}$ & DHS return temperature, ${ }^{\circ} \mathrm{C}$ \\
\hline$\Delta \bar{t}(Q)$ & logarithmic temperature difference in $\mathrm{DH},{ }^{\circ} \mathrm{C}$ \\
\hline$t_{\mathrm{amb}}$ & ambient (outside) air temperature, ${ }^{\circ} \mathrm{C}$ \\
\hline$N_{\mathrm{GT}}$ & gas turbine electrical capacity, MW \\
\hline$N_{\mathrm{HP}}$ & $\begin{array}{l}\text { electrical capacity of steam turbine high pressure section, } \\
\text { MW }\end{array}$ \\
\hline$N_{\mathrm{LP}}$ & electrical capacity of steam turbine low pressure section, $\mathrm{MW}$ \\
\hline$G_{\mathrm{g}}$ & natural gas consumption, $\mathrm{kg} / \mathrm{s}$ \\
\hline
\end{tabular}

\section{DESCRIPTION}

Riga DHS is divided into two main areas located on the left and right banks of the River Daugava (the Right Bank), which consist of several heating zones depending on the heating source.

The Right Bank consumes approximately $70 \%$ of the total heat supplied to Riga city. Right Bank DHS is mainly provided by large-scale CHP plants Riga TEC-1 (CHP-1) and 


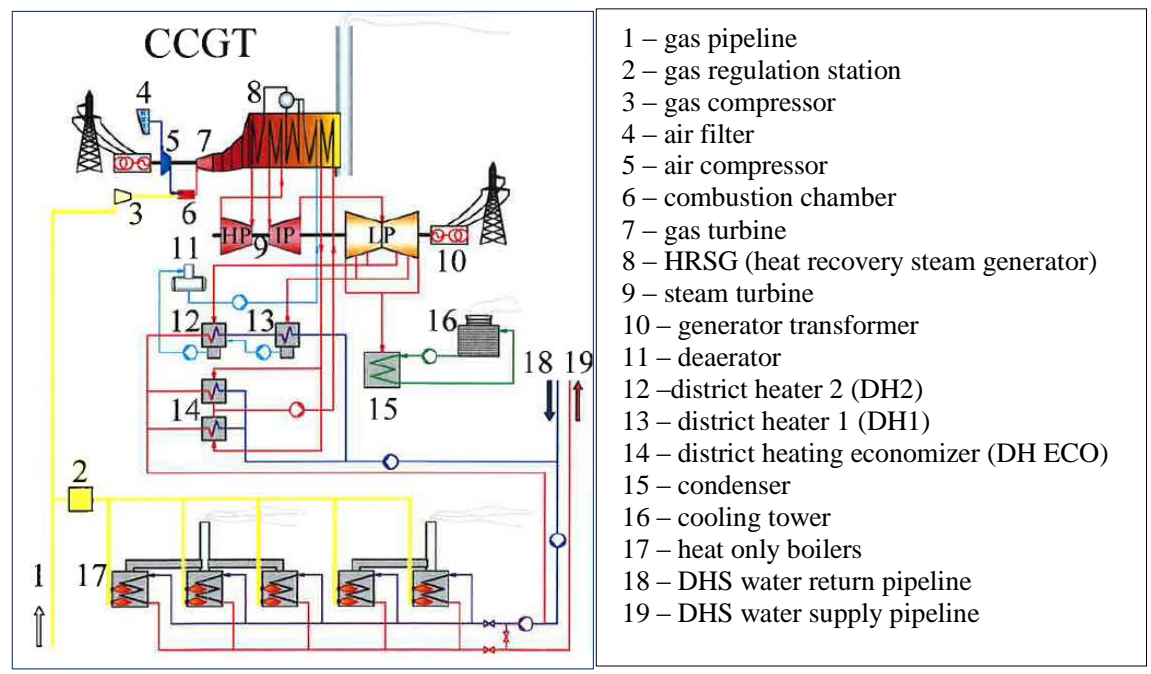

Fig. 1. Riga CHP-2 CCGT-1 scheme.

Riga TEC-2 (CHP-2) owned by Latvenergo AS (approximately $98 \%$ of the total Right Bank heat supply).

The Riga CHP plants are mainly operated with the goal of providing the required heat load, mainly operating in the cogeneration mode. The generation of electricity is mainly subordinated to the consumption of heat, which in turn depends on the climatic conditions (air temperature) and the duration of the heating season, as well as to the electricity market situation [9].

Riga CHP-2 is the largest combined heat and power plant in Latvia which was launched in 1973. The reconstruction of Riga TEC-2 was initiated in 2006, the first power unit was commissioned in late 2008 and the second power unit was commissioned in late 2013. Two combined-cycle gas turbine (CCGT) units and five water boilers are currently exploited at Riga CHP-2. Upon the commissioning of the second power unit, the electrical capacity of Riga TEC-2 in cogeneration mode reaches $832 \mathrm{MW}_{\mathrm{el}}$, while the total thermal energy capacity of the two power units reaches $544 \mathrm{MW}_{\text {th }}$ in cogeneration mode. The full thermal energy capacity of Riga CHP-2, including the boilers, is $1.124 \mathrm{MW}_{\text {th }}$ [9].

In this paper CCGT-1 was selected to analyse the impact of decreasing DHS supply temperature. CCGT-1 was put in operation in 2008 and 4-5 years of its operation are enough to analyse the operational data. CCGT-1 principal scheme is shown on Fig. 1.

Temperature schedule $130 / 70{ }^{\circ} \mathrm{C}$ used in Riga city DHS was implemented at the early stage of district heating development. It reflects the real situation of that period: growing heat consumption, high heat losses due to technical incapability of thermal isolation of DHS network pipes. Nowadays new technologies are introduced to improve the DHS network and heat loss from transporting the heat is significantly reduced. After the already implemented improvements, the next step to be considered is reviewing the temperature schedule in order to reduce DHS supply temperature.

Analysis of Riga CHP-2 operation regimes shows that the most important factor which limits the maximally efficient operation of the modern and powerful units of the plant is the lack of heat carrier flow (DHS water) to provide nominal flow through district heaters (DH). Decreasing DHS supply temperature would lead to an increase in the hydraulic load of CCGT units.

The main parameter which impacts the efficiency of steam turbine is the pressure at steam extraction. Reducing this pressure increases the heat energy difference between the sections and therefore increases power generation capacity. The pressure at steam extraction depends on the steam condensing conditions in DH: the temperature of DHS water entering the heater and its flow.

As known, the DHS return temperature is defined by the condition of heating and hot water systems of the consumers and their habits of consuming the heat. These factors are not analysed in this paper therefore DHS return temperature was not modified within modelling CCGT. One of the available methods to increase heat exchange efficiency in $\mathrm{DH}$ is to increase the flow to nominal values.

\section{METHODS}

For further analysis, CHP-2 CCGT-1 data were used. Due to the unavailability of commercial data of the installed units, the model was built using standard operation modes and empirical analysis.

CHP-2 CCGT-1 project developers provided operating parameters for regimes at a range of ambient temperature, DHS supply and return temperature, which complies with approved DHS temperature schedule, as well as varying DHS water flow. According to the aforementioned operational modes, the main relations between different steam turbine parameters were defined and the mathematical model of the CCGT operating at nominal load was built. In order to develop a model and analyse the results, the references [3], [5], [10-16] were studied and used. The information on water and steam properties was provided by the references [17-19]. The model is developed for regimes at nominal load and describes only cogeneration mode. 
The main algorithm of the model and basic empirical equations are described below.

Relation between district water heaters $Q_{\mathrm{DH} 1}$ and $Q_{\mathrm{DH} 2}$ capacity and $t_{\mathrm{r}}$ was defined for DH1 $\left(R^{2}=0.9994\right)$ and $\mathrm{DH} 2$ $\left(R^{2}=0.9998\right)$ :

$$
\begin{gathered}
Q_{\mathrm{DH} 1}=-0.05212 \cdot t_{\mathrm{r}}^{2}+9.61653 \cdot t_{\mathrm{r}}-222.77415 \\
Q_{\mathrm{DH} 2}=0.04803 \cdot t_{\mathrm{r}}^{2}-9.84336 \cdot t_{\mathrm{r}}+466.70544
\end{gathered}
$$

Relation between $\mathrm{DH} 1$ and $\mathrm{DH} 2$ logarithmic temperature difference and heat capacity:

$$
\begin{aligned}
& \Delta \bar{t}\left(Q_{\mathrm{DH} 1}\right)=0.0004873 \cdot Q_{\mathrm{DH} 1}^{2}-0.06026 \cdot Q_{\mathrm{DH} 1}-7.4127, \\
& R^{2}=0.9895 \\
& \Delta \bar{t}\left(Q_{\mathrm{DH} 2}\right)=-0.0001653 \cdot Q_{\mathrm{DH} 2}^{2}+0.0905 \cdot Q_{\mathrm{DH} 2}-0.7149, \\
& R^{2}=0.9999
\end{aligned}
$$

On the basis of equations $1-4$, steam turbine calculations are performed at the nominal DHS water flow through $\mathrm{DH}$ for the operational modes provided by the CCGT-1 developer company in the following sequence: DH1 heat load; water temperature at the exit from $\mathrm{DH} 1$; logarithmic temperature difference in DH1; saturation temperature in DH1; steam pressure at DH1; the same parameters defined for DH2; entropy at steam turbine low pressure section (LP) entrance; enthalpy at the end of adiabatic expansion process of LP section (LP entrance - $\mathrm{DH} 2$ ); steam pressure in $\mathrm{DH} 2$; available heat difference for the section LP entrance - DH2, used heat difference of the section LP entrance - DH2; electrical capacity of the mentioned section; actual steam enthalpy in DH2; steam entropy in DH2; steam enthalpy at the end of adiabatic expansion process from parameters in $\mathrm{DH} 2$ to pressure in $\mathrm{DH} 1$; available heat difference in the section $\mathrm{DH} 2-\mathrm{DH} 1$; steam flow in $\mathrm{DH} 2$; steam flow in the section $\mathrm{DH} 2-\mathrm{DH} 1$; efficiency of the section DH2-DH1; used heat difference of the section DH2DH1; electrical capacity of the section DH2-DH1, LP electrical capacity.

To have an opportunity to define the total steam turbine capacity at any ambient temperature and return district heating water temperature, using the data provided by CCGT-1 developer company, the following equations are built and used in the model:

- Relation between gas turbine electrical capacity and ambient temperature $\left(t_{\mathrm{amb}} ; R^{2}=0.9965\right)$ :

$$
N_{\mathrm{GT}}\left(t_{\mathrm{amb}}\right)=-0.006771 \cdot t_{\mathrm{amb}}^{2}-0.45297 \cdot t_{\mathrm{amb}}+290.3961
$$

- Relation between the electrical capacity of steam turbine high pressure section and the ambient temperature $\left(R^{2}=0.9907\right)$ :

$$
N_{\mathrm{HP}}\left(t_{\mathrm{amb}}\right)=0.000001170 \cdot t_{\mathrm{amb}}^{2}+0.025771 \cdot t_{\mathrm{amb}}+31.697
$$

- Relation between steam turbine heat capacity and return district heating water temperature:

$$
Q_{\mathrm{DHIDH} 2}=-0.004075 \cdot t_{\mathrm{r}}^{2}-0.22818 \cdot t_{\mathrm{r}}+243.9600
$$

- Relation between steam turbine low pressure section electrical capacity and return district heating temperature $\left(R^{2}=0.9999\right)$ :

$$
N_{\mathrm{LP}}\left(t_{\mathrm{r}}\right)=-0.01143 \cdot t_{\mathrm{r}}^{2}+0.71386 \cdot t_{\mathrm{r}}+34.1687
$$

- Relation between CCGT-1 fuel consumption and the ambient temperature $\left(R^{2}=0.9988\right)$ :

$$
G_{\mathrm{g}}\left(t_{\mathrm{amb}}\right)=-0.0003341 \cdot t_{\mathrm{amb}}^{2}-0.029686 \cdot t_{\mathrm{amb}}+15.4947
$$

Thus, the described algorithm and equations form the mathematical model of Riga CHP-2 CCGT-1, which gives an opportunity to define CCGT electrical generation capacity and heat capacity of DH1 and DH2 at the nominal load at varying ambient temperature and DHS return temperature.

\section{RESULTS}

The mathematical model of CCGT units was successfully developed and approbated using the standard operating modes provided by the CCGT-1 developer company. Accuracy ratio for most of the analysed parameters did not exceed $1 \%-2 \%$. The main parameters to characterise operating modes are shown in Table I. Simulation results for four different operation modes (at ambient temperature $-20{ }^{\circ} \mathrm{C},-16{ }^{\circ} \mathrm{C},-8{ }^{\circ} \mathrm{C}, 0{ }^{\circ} \mathrm{C}$ ) can be compared to the modes provided by the CCGT-1 developer company - all these parameters describe full load operation. The results of the analysis show that increasing DHS water flow through $\mathrm{DH}$ leads to decreasing the temperature at the exit from $\mathrm{DH} 1$ by $0.7{ }^{\circ} \mathrm{C}-9.32{ }^{\circ} \mathrm{C}$ and at the exit from $\mathrm{DH} 2$ by $0.9^{\circ} \mathrm{C}-0.8^{\circ} \mathrm{C}$. Lower temperatures result in increasing steam turbine low pressure section electrical capacity by $1 \%-45 \%$.

The maximum difference between actual and nominal water flow through DH leads to the greatest growth of steam turbine low pressure section electrical capacity. Operational modes which anticipate the water flow close to nominal do not have significant growth of steam turbine low pressure section electrical capacity.

TABLE II

EXAMPLE OF COMPARISON OF STANDARD AND SIMULATED OPERATIONAL MODES (LOAD $100 \%$, AMBIENT TEMPERATURE $-8{ }^{\circ} \mathrm{C}$ )

\begin{tabular}{|l|c|c|}
\hline & $\begin{array}{c}\text { Standard } \\
\text { operat. } \\
\text { mode }\end{array}$ & $\begin{array}{c}\text { Simulated } \\
\text { operat. } \\
\text { mode }\end{array}$ \\
\hline $\begin{array}{l}\text { Return district heating water temperature } t_{\mathrm{r}}, \\
{ }^{\circ} \mathrm{C}\end{array}$ & 56 & 56 \\
\hline Water temperature at the exit from $\mathrm{DH} 1,{ }^{\circ} \mathrm{C}$ & 81.41 & 77.04 \\
\hline Water temperature at the exit from $\mathrm{DH} 2,{ }^{\circ} \mathrm{C}$ & 92 & 88.69 \\
\hline Water flow through $\mathrm{DH}, \mathrm{kg} / \mathrm{s}$ & 1431.42 & 1729.2 \\
\hline LP electrical capacity, $\mathrm{MW}$ & 35.70 & 38.26 \\
\hline DH1 heat capacity, $\mathrm{MW}$ & 152.3 & 152.3 \\
\hline DH2 heat capacity, $\mathrm{MW}$ & 63.5 & 66.1 \\
\hline
\end{tabular}




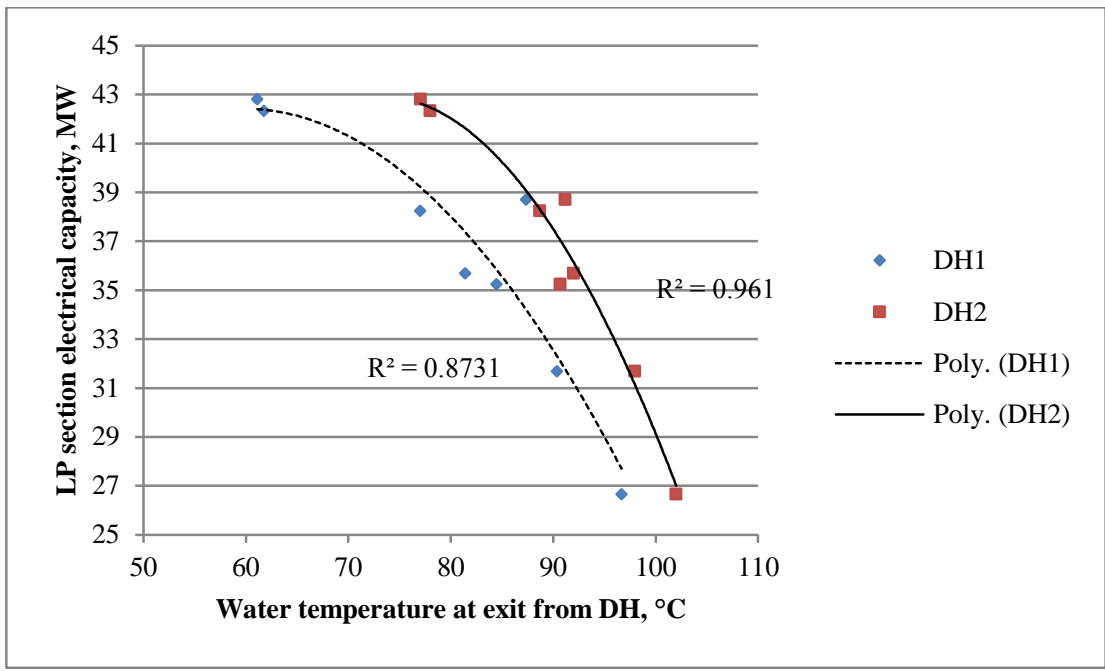

Fig. 2. Relation between LP section electrical capacity and water temperature at the exit from DH.

Capacities of the high and intermediate pressure steam turbine sections remain constant as these sections are not influenced by the operation of DH1 and DH2. The operation mode which gives the greatest growth of electrical capacity if the water flow is increased to nominal is the mode at ambient temperature $-16^{\circ} \mathrm{C}$. The reason for this is the fact that, according to CCGT-1 standard operation modes described by the unit's developer company, the mode at ambient temperature $-16^{\circ} \mathrm{C}$ has the lowest DHS water flow through $\mathrm{DH}$ and, accordingly, the highest DHS water temperature at the exit. This fact differs from the actual operational conditions as can be concluded from further analysis.

The results of simulation reflect the relation between the water temperature at the exit from DH1 and DH2 and the electrical capacity of steam turbine low pressure section (Fig. 2).

CCGT-1 mathematical model gave an opportunity to use the relations between the parameters to analyse actual operational modes of the plant. The actual operation data were used at a range of ambient temperature from $-12{ }^{\circ} \mathrm{C}$ to $10{ }^{\circ} \mathrm{C}(2012-$ 2013 data) and various electrical loads. One of the limitations of the CCGT-1 mathematical model is the opportunity to analyse the data only at nominal operational modes and excluding condensing modes. Therefore the model was used to simulate operational modes with nominal water flow through DH using the actual values of DHS return water temperature and ambient temperature characterising CCGT-1 operational regimes.

Then, using the empirical equation, based on the actual operational data (relation between CCGT-1 electrical capacity and fuel consumption), fuel consumption of the simulated mode is compared with fuel consumption in the actual mode converted to nominal load.

Natural gas consumption reduction in the simulated mode with nominal DHS water flow through DH and therefore with the decreased DHS supply temperature is up to $3 \%$ (see Fig. 3) and the average fuel consumption reduction in the analysed modes is $1.4 \%$.

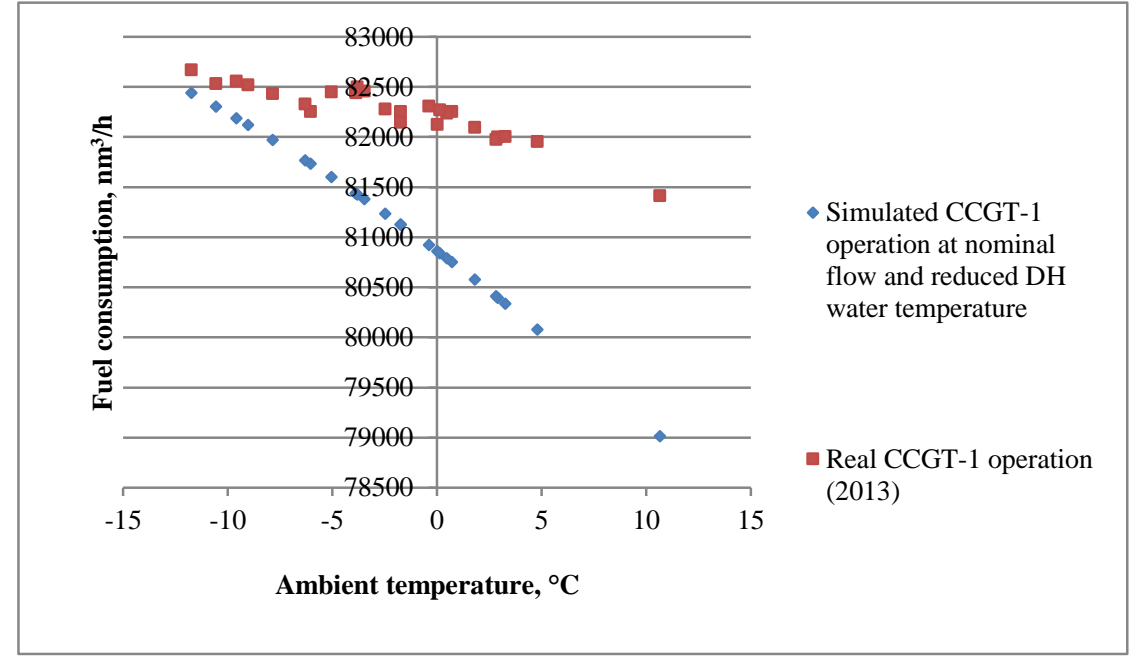

Fig. 3. Fuel consumption at actual and simulated CCGT operation. 
District heating economizer (DH ECO) was not analysed in this paper. In the CCGT-1 mathematical model it was assumed that the heat load of DH ECO is $44 \mathrm{MW}$ which is close to maximum according to actual operational data. ECO DH is relatively independent from the operation of the turbine and does not have any impact on the steam turbine on condition that the water flow through DH is not reduced to direct the part of the flow to DH ECO. Decreasing DHS supply temperature gives an opportunity to direct the water flow to DH ECO which is equal to the nominal flow of this unit without reducing the flow through the main heaters (DH1, DH2). The only limitation to increase DH ECO heat load is the flue gas temperature due to formation of the condensate on the heating surfaces and in the stack.

\section{V.CONCLUSION}

In this study, a mathematical model of a CCGT unit was developed to analyse the possibilities for the optimisation of its operation by reducing DHS supply temperature and increasing DH water flow.

Due to unavailability of data, significant reduction of DHS supply temperature was not discussed in this paper. At this moment there are no detailed studies available to the authors reflecting how the DHS supply temperature and flow could be modified avoiding a negative impact on consumers at current DHS conditions. Therefore as a first step the decrease of temperature to ensure DHS water flow which is close to nominal flow of district heaters was studied.

The analysis of the standard modes show that increasing DHS water flow through DH to nominal values leads to decreasing the temperature at the exit from $\mathrm{DH} 1$ by $0.7^{\circ} \mathrm{C}-9.32^{\circ} \mathrm{C}$ and at the exit from DH2 by $0.9^{\circ} \mathrm{C}-10.8^{\circ} \mathrm{C}$. Lower temperatures result in increasing steam turbine low pressure section electrical capacity by $1 \%-45 \%$.

The analysis of the actual CCGT unit operational modes converted to nominal modes reflected natural gas consumption reduction by up to $3 \%$ (or $2399 \mathrm{~nm}^{3} / \mathrm{h}$ ) and the average fuel consumption reduction in the analysed modes was $1.4 \%$ (or $\left.1101 \mathrm{~nm}^{3} / \mathrm{h}\right)$.

It is concluded that providing nominal water flow through $\mathrm{DH}$ and as a result of it reduction of the temperature at the exit from $\mathrm{DH}$ results in increasing electrical load or reduced fuel consumption if it is not necessary to increase the load. Temperature at the exit from CCGT in such conditions can vary depending on operational mode and in the case it is too low to ensure approved DHS supply temperature schedule, the units can operate in combination with heat only boilers.

The results of this study reflect optimisation opportunities of CCGT operation by providing optimal operational conditions which mainly depend on operation of DHS. In further studies the model of the unit should be improved and used for analysis of possible limitations of decreasing DHS supply temperature and increasing DHS water flow.

\section{REFERENCES}

1. Lund, H., Werner, S., Wiltshire, R., Svendsen, S., Thorsen, J. E., Hvelplund, F., Mathiesen, B. V. 4th Generation District Heating
(4GDH). Integrating smart thermal grids into future sustainable energy systems. Energy, 2014, No. 68, pp. 1-11.

http://dx.doi.org/10.1016/j.energy.2014.02.089

2. Elsman, P. Copenhagen District Heating System. Application for the Global District Energy Climate Award, 2009. 43 p.

3. Dalla Rosa, A. Low-Temperature District Heating for Energy-Efficient Communities. Technical University of Denmark, 3.10.2012. Available: http://www.nachhaltigwirtschaften.at [Accessed on 3.07.2014.]

4. Zigurs, A., Turlajs, D., Kreslins, A., Cers, A., Sorocins, A. Improvement of efficiency of district heating systems in Latvia. In: $21 \mathrm{st}$ World Energy Congress: Issue 1.6: Closer Integration for Infrastructure, Adequacy and Efficiency, Montreal, Canada, September, 12-16, 2010, pp. 1-13.

5. Saarinen, L. Model-based control of district heating supply temperature. Project P08-819 Report 2010, Varmeforsk Report Databased. Available: http://www.varmeforsk.se [Accessed 03.07.2014].

6. Ziemele, J., Vīgants, G., Vītoliṇ̌s, V., Blumberga, D., Veidenbergs, I. District Heating Systems Performance Analyses. Heat Energy Tariff. Environmental and Climate Technologies. vol. 13, 2014, pp.32-43. http://dx.doi.org/10.2478/rtuect-2014-0005

7. Žìgurs, A. Centralizêtāss siltumapgādes sistēmu efektivitāte. $\mathrm{PhD}$ thesis. Riga: Riga Technical University, 2009.

8. Latvenergo AS information and Riga TEC-2 (CHP-2) operational data, 2012-2013.

9. Latvenergo AS Generation, 2014. Available: www.latvenergo.lv [Accessed 21.07.2014.].

10. Godoy, E., Scenna, N. J., Benz, S. J. Families of optimal thermodynamic solutions for combined cycle gas turbine (CCGT) power plants. Applied Thermal Engineering, 2010, No. 30, pp. 569-576. http://dx.doi.org/10.1016/j.applthermaleng.2009.10.022

11. Hasan, N., Rai, J. N., Arora, B. B. Optimization of CCGT power plant and performance analysis using MATLAB/Simulink with actual operational data. SpringerPlus, 2014. No. 3, 275 p. http://dx.doi.org/10.1186/2193-1801-3-275

12. Medina-Flores, J. M., Picon-Nunez, M. Modelling the power production of single and multiple extraction steam turbines. Chemical Engineering Science, 2010, No. 65, pp. 2811-2820. http://dx.doi.org/10.1016/j.ces.2010.01.016

13. Palsson, O. P. Stochastic modeling, control and optimization of district heating systems. $\mathrm{PhD}$ Thesis. Lyngby: The Technical University of Denmark, 1993, 304 p.

14. Saarinen, L. Modelling and control of a district heating system. M. Sc. Thesis. Uppsala: Uppsala University, 2008, 67 p.

15. Urosevic, D., Gvozdenac, D., Grkovic, V. Calculation of the power loss coefficient of steam turbine as a part of the cogeneration plant. Energy, 2013, No. 59, pp.642-651 http://dx.doi.org/10.1016/j.energy.2013.07.010

16. Shhegljaev, A. V. Parovye turbiny. Jenergoatomizdat, 1993. 384 str. (In Russian).

17. Steam Tables (IAPWS) - Scientific Formulation, Available: www.steamtablesonline.com [Accessed 2013-2014].

18. Revised Release on the IAPWS Industrial Formulation 1997 for the Thermodynamic Properties of Water and Steam. Lucerne: The International Association for the Properties of Water and Steam, August 2007 - [Accessed 11.07.2014]. Available: http://www.iapws.org/relguide/IF97-Rev.pdf

19. Vokova, A., Mashatin, V., Hlebnikov, A., Siirde, A. Methodology for the Improvement of Large District Heating Networks. Scientific Journal of Riga Technical University Environmental and Climate Technologies, 2013, No. 10, pp. 39-45. http://dx.doi.org/10.2478/v10145-012-0009-7

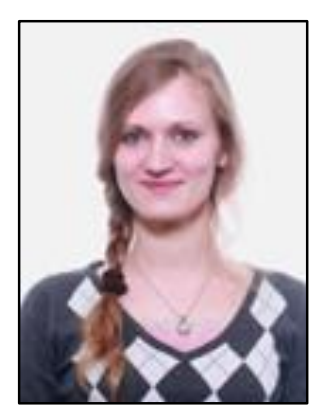

Alona Bolonina is a $\mathrm{PhD}$ student at the Institute of Energy Systems and Environment, studying environmental optimization of combined heat and power plants operation in district heating systems. PhD studies followed after gaining M. sc. degree (2008) and B. sc. degree (2006) in Environmental Science. Since 2009 is a Head of Environmental Management Unit at Latvenergo AS.

E-mail: alona.bolonina@rtu.lv 


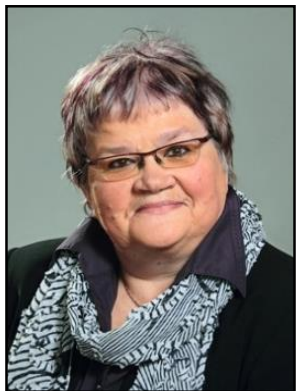

Dagnija Blumberga, Dr. habil. sc. ing., professor at the Riga Technical University, Institute of Energy Systems and Environment. She has Thermal Engineer Diploma (1970). Doctoral degree was defended in Lithuanian Energy Institute, Kaunas (1988). Doctor Habilitus Thesis "Analysis of Energy Efficiency from Environmental, Economical and Management Aspects" was prepared in Royal Institute of Technology (KTH) Stockholm (1995) and was defended in Faculty of Energy and Electronics, Riga Technical University (1996). Professor Dagnija Blumberga has been part of academic staff of Faculty of Energy and Electrotechnics, Riga Technical University since 1976 and director of Institute of Environmental Protection and Energy Systems since 1999. The main research area is renewable energy resources, heating systems and climate technologies. She has participated in different local and international projects related to climate change, energy and environment as well as is author of more than 200 publications and 15 books.

E-mail: dagnija.blumberga@ rtu.lv

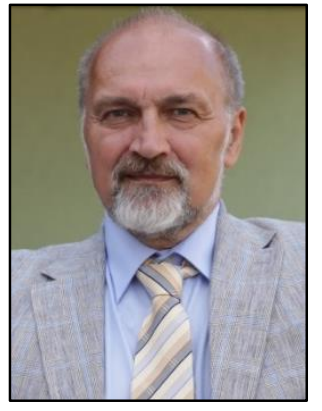

Genadijs Bolonins in 1972 graduated from Moscow Power Engineering Institute, specialty "Turbine construction", in 1983 graduated from University of Latvia, specialty "Mathematics". Since 1975 has been working at Riga TEC-2. Over the last years is a Senior Mechanical Engineer in Latvenergo AS CHPP Technical Unit.

E-mail: genadijs.bolonins@ @atvenergo.lv 